\title{
Performance of the Soil Vulnerability Index with respect to slope, digital elevation model resolution, and hydrologic soil group
}

\author{
S. Lohani, C. Baffaut, A.L. Thompson, N. Aryal, R.L. Bingner, D.L. Bjorneberg, D.D. Bosch, R.B. \\ Bryant, A. Buda, S.M. Dabney, A.R. Davis, L.F. Duriancik, D.E. James, K.W. King, P.J.A. Kleinman, \\ M. Locke, G.W. McCarty, L.A. Pease, M.L. Reba, D.R Smith, M.D. Tomer, T.L. Veith, M.R. Williams, \\ and L.M.W. Yasarer
}

\begin{abstract}
Soil erosion and nutrient loss from surface runoff and subsurface leaching are critical problems for cultivated land. Conservation initiatives show a persistent need for fieldscale cropland vulnerability assessments to inform farm management options and prioritize efforts at watershed or regional scales. The Soil Vulnerability Index (SVI) was developed by USDA's Natural Resources Conservation Service (NRCS) to assess inherent vulnerability of cropland to surface runoff and leaching using readily available soil and topographic inputs: hydrologic soil group, slope, erodibility K-factor, coarse fragments, and organic carbon (C). The SVI has been evaluated in a few watersheds but requires further evaluation across a wider range of physiographic and climatic conditions. The objective of this study was to evaluate the ability of the SVI to correctly identify vulnerability class based on slope, digital elevation model (DEM) resolution, hydrologic soil group, and soil erodibility across 13 of USDA's Conservation Effects Assessment Project (CEAP) watersheds. The SVI classification was consistent with model output classification with a similarity rate of more than $70 \%$ when the SVI component corresponded to the primary route of loss for nutrients or sediment. Results showed that SVIs were consistent with local scientific expertise about the site vulnerability to runoff and leaching, and were particularly useful in areas with mixed slopes and hydrologic soil groups. In watersheds with uniform C or D hydrologic soil groups, the SVI was primarily driven by slope. In these cases, it was important to use a digital elevation map with 10 $\mathrm{m}$ resolution or higher to more finely distinguish vulnerability. In areas with uniform slopes and hydrologic soil group, and in areas with uniformly steep slopes, the SVI was not able to identify fields with greater or lower vulnerability than others. In these cases, vulnerability assessments required additional factors: depth of restrictive layer, clay content, slope length, and landscape position. While the SVI was able to categorize vulnerability correctly in mixed soil and slope conditions, findings from this project highlight the need for incorporating DEM-sourced slope and other factors like depth of restrictive layer, clay content, slope length, and landscape position into the SVI to ensure that the SVI is applicable to the broad range of geomorphic conditions found in the United States.
\end{abstract}

Key words: conservation practices-erodibility-erosion-hydrologic soil groupleaching-runoff

Nutrient impairment from excessive nonpoint source pollution (NPS) is a difficult challenge in modern agricultural practices due to the spatial diffusion of the sources of NPS pollution (Sharpley et al. 2011). Many studies have documented the effects of cropland conservation practices (e.g., conservation cover and grassed waterway) at reducing field-scale NPS pollution (Douglas-Mankin et al. 2013; Jokela et al. 2004; Nangia et al. 2010; Sharpley et

Sapana Lohani is a postdoctoral scholar in the Department of Biology, University of NevadaReno, Nevada. Claire Baffaut is a research hydrologist at the Cropping Systems and Water Quality Research Unit, USDA Agricultural Research Service (ARS), Columbia, Missouri. Allen L. Thompson is a professor in the Department of Bioengineering, University of Missouri, Columbia, Missouri. Niroj Aryal is an assistant professor of Biological Engineering at North Carolina Agricultural and Technical State University, Greensboro, North Carolina. Ronald L. Bingner is an agricultural engineer at the USDA ARS National Sedimentation Laboratory, Oxford, Mississippi. David L. Bjorneberg is a supervisory agricultural engineer at the USDA ARS Northwest Irrigation and Soils Research Unit, Kimberly, Idaho. David D. Bosch is a research hydraulic engineer at the USDA ARS Southeast Watershed Research Laboratory, Tifton, Georgia. Ray B. Bryant is a research soil scientist and Anthony Buda is a research hydrologist at the USDA ARS Pasture Systems and Watershed Management Research Unit, University Park, Pennsylvania. Seth M. Dabney is a collaborator with the National Sedimentation Laboratory, Oxford, Mississippi. Austin R. Davis is a graduate student in the Department of Bioengineering, University of Missouri, Columbia, Missouri. Lisa F. Duriancik is the Conservation Effects Assessment Project (CEAP) watersheds leader at the Resources Inventory and Assessment Division, USDA Natural Resources Conservation Service (NRCS), Beltsville, Maryland. David E. James is a geographic information specialist at the USDA ARS Agroecosystems Management Research Unit, Ames, lowa. Kevin W. King is research leader and agricultural engineer at the USDA ARS Soil Drainage Research Unit, Columbus, Ohio. Peter J.A. Kleinman is research leader and soil scientist at the USDA ARS Pasture Systems and Watershed Management Research Unit, University Park, Pennsylvania. Martin Locke is a research soil scientist and the laboratory director at the USDA ARS National Sedimentation Laboratory, Oxford, Mississippi. Gregory W. McCarty is a research soil scientist at the USDA ARS Hydrology and Remote Sensing Laboratory, Beltsville, Maryland. Lindsay A. Pease is an assistant professor and extension specialist at University of Minnesota-Twin Cities, Minneapolis, Minnesota. Michele L. Reba is a research hydrologist with USDA ARS Delta Water Management Research Unit, Jonesboro, Arkansas. Douglas R. Smith is a research soil scientist at the USDA ARS Grassland Soil and Research Laboratory, Temple, Texas. Mark D. Tomer is a soil scientist at the USDA ARS Agroecosystems Management Research Unit, Ames, lowa. Tamie L. Veith is an agricultural engineer at the USDA ARS Pasture Systems and Watershed Management Research Unit, University Park, Pennsylvania. Mark R. Williams is a research agricultural engineer at the USDA ARS National Soil Erosion Research Unit, West Lafayette, Indiana. Lindsey M.W. Yasarer is a research hydrologist at the USDA ARS National Sedimentation Laboratory, Oxford, Mississippi. 
al. 2006; USDA NRCS 2012, 2016). In spite of beneficial edge-of-field effects of conservation practices, watershed-scale benefits of conservation programs remain elusive and, in some cases, even undetectable (Chaubey et al. 2010; Inamdar et al. 2002; Park et al. 1994; Tomer et al. 2003, 2014; Tomer and Locke 2011). Multiple reasons contribute to this lack of observable benefit, including the legacy effect of past management practices (Sharpley et al. 2013) or the low adoption rate (Jackson-Smith et al. 2010; Ryan et al. 2003). However, research has also shown that conservation practices have often not been implemented in the most vulnerable areas (Gale et al. 1993; Nowak and Cabot 2004; Nowak et al. 2006; Strauss et al. 2007; Tomer et al. 2003; Tomer and Locke 2011; Yang et al. 2005). Where this has been done, data from appropriate monitoring designs have documented improvements at watershed level (Osmond et al. 2012). However, one prerequisite for practices to be implemented where they are most needed is to identify these high vulnerability areas, which remains technically challenging (Tomer et al. 2013). Thus, there is a need for targeting tools to define these areas. Overlaying the presence or absence of conservation management practices can then help assess where new practices are needed.

Several indices and tools can help to identify these critical source areas. For example, remote sensing, geographic information system (GIS), and the Revised Universal Soil Loss Equation (RUSLE) (Renard et al. 1991) are routinely used to map soil erosion risk (Meals et al. 2012). Watershed-scale computer simulation models like the Agricultural Policy Environmental eXtender (APEX) model (Williams and Izaurralde 2005) and the Soil and Water Assessment Tool (SWAT) model (Arnold et al. 1998) are hydrologic models extensively used to understand the linkage between land use and management, and outputs like sediment, runoff, or yield (Busteed et al. 2009; Douglas-Mankin et al. 2013; Lee et al. 2018; Gassman et al. 2007). However, these tools are complicated and require multiple data sets and modeling expertise, many of which are typically lacking at the field, county, and state levels.

A time and cost effective, less computationally intensive approach is to use indices that rely on readily available input parameters. For example, the Phosphorus Index (PI) can rank fields based on their vulnerability to phosphorus (P) losses (Lemunyon and
Gilbert 1993). The Conductivity Claypan Index (CCI), developed by Mudgal et al. (2012), classifies fields or subfield areas based on the vulnerability to surface runoff. The Water Quality Index (WQI) combines measured values of multiple water quality factors such as dissolved oxygen $(\mathrm{O}), \mathrm{pH}$, biological $\mathrm{O}$ demand, C-O demand, E. coli, temperature, and nutrients (nitrogen $[\mathrm{N}]$ and $\mathrm{P}$ ) into a single value used for evaluating the quality of water in rivers, streams, and lakes (Lal 2011). The Water Quality Index for Agricultural Runoff (WQIag) is also a web-based index that uses multiple field characteristics and management factors to evaluate effectiveness of conservation practices for improving water quality of runoff water from agricultural lands (Lal and McKinney 2012). An equally simple index that does not require water quality measurements is the Soil Vulnerability Index (SVI).

The SVI was developed by USDA Natural Resources Conservation Service (USDA NRCS) as a product of the Conservation Effects Assessment Project (CEAP) to quantify cropland vulnerability to runoff and leaching. The SVI was originally developed for large-scale, regional analysis support (USDA NRCS 2012). The SVI uses publicly available data from the SSURGO database (Soil Survey Staff 2015) to categorize land into four vulnerability classes-low, moderate, moderately high, and high. The SVI runoff component defines the potential risk of sediment and sediment-bound contaminants' loss via surface runoff, whereas the SVI leaching component depicts the potential risk of nutrient loss through infiltration and subsurface flows (e.g., lateral seepage, return flow, and tile drainage). Details on the development and purpose of the SVI are discussed by Thompson et al. (2020).

An initial evaluation of the SVI was conducted by Chan et al. (2017) in the Goodwater Creek Experimental Watershed in Missouri. One finding was that, for watershed planning purposes and for individual field evaluation, the SVI produced more useful results by using slopes derived from a $10 \mathrm{~m}$ digital elevation model (DEM) than from the SSURGO representative slope (Chan et al. 2017). These results emphasize the importance of using $10 \mathrm{~m}$ DEMs, currently available for the entire United States, in addition to SSURGO polygons and soil properties. Lee et al. (2018) compared SVI sediment risk categories against
SWAT-modeled total and organic $\mathrm{N}$ loads from cropland in two adjacent subwatersheds with contrasting soil characteristics within the Choptank River watershed in the Chesapeake Bay watershed. The paper concluded that vulnerability classification based on model outputs matched the SVI runoff classification for variables that relied on topographic characteristics for transport (e.g., organic N) and the SVI leaching classification scheme for constituents that are transported based on soil water movement characteristics (e.g., nitrates $\left[\mathrm{NO}_{3}\right]$ ). Hence, the SVI has a strong potential to serve as an initial water quality vulnerability classification index without requiring water quality data inputs. Yasarer et al. (2020) compared the SVI vulnerability classification against outputs from the Annualized Agricultural Non-Point Source (AnnAGNPS) model in two watersheds in Lower Mississippi. The study concluded that the SVI is effective for identifying areas that could potentially contribute to NPS pollution.

In spite of these regionally specific evaluations, the SVI requires further validation across a range of physiographic and climatic conditions. The objective of this study was to assess the ability of the SVI to correlate with local scientific knowledge on identifying vulnerability class based on slope, DEM resolution, hydrologic soil group, and soil erodibility across 13 CEAP watersheds. This study complements SVI evaluations described in companion articles in this issue of the Journal of Soil and Water Conservation.

\section{Materials and Methods}

Study Area. A brief overview of the 13 sites (figure 1) can be found in table 1, and additional details are given by Thompson et al. (2020). For this study, the sites were grouped based on croplands in dominant slope: steep slopes $(>6 \%)$, flat slopes $(<2 \%)$, and mixed slopes.

Steep Slopes. WE-38 $\left(7 \mathrm{~km}^{2}\right)$ was an intensively monitored and researched catchment within the Mahantango Creek watershed in central Pennsylvania and was characterized by steep slopes (>6\%). Land use in WE-38 watershed included cultivated land (54.9\%), woodlands (39.6\%), pasture (3.2\%), and developed area $(2.3 \%)$. Cropping systems varied by operation, with most including corn (Zea mays L.) and soybeans (Glycine max [L.] Merr.) in rotation with other crops, including small 
Figure 1

Study areas.

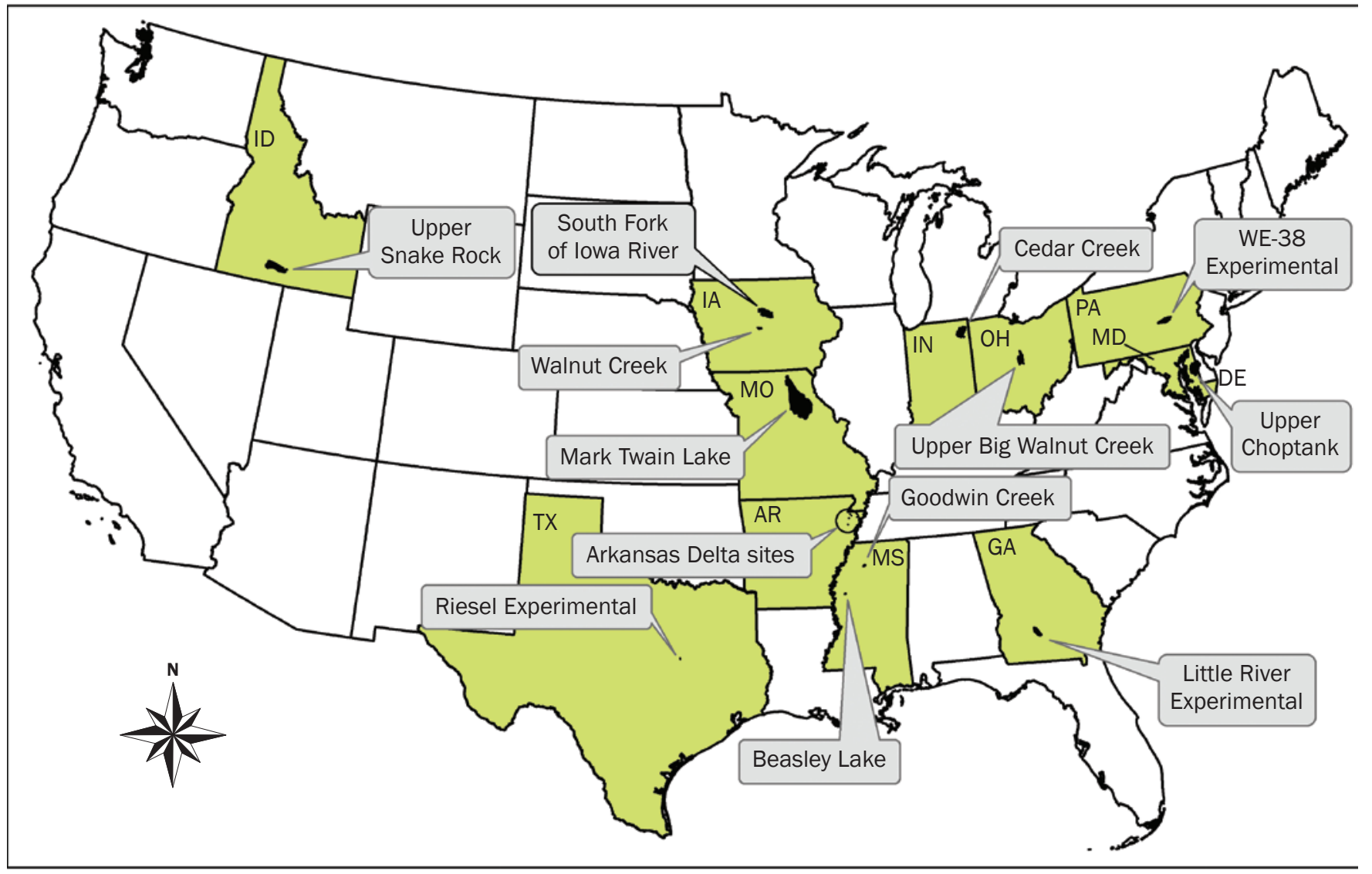

Table 1

Study sites.

\begin{tabular}{|c|c|c|c|c|}
\hline Sites & Area $\left(\mathbf{k m}^{2}\right)$ & $\begin{array}{l}\text { Cropland area } \\
\text { in watershed (\%) }\end{array}$ & Dominant slope & $\begin{array}{l}\text { Proportion of watershed in each } \\
\text { hydrologic soil group (A/B/C/D) (\%) }\end{array}$ \\
\hline WE-38, Pennsylvania & 7 & 55 & Steep slopes (>6\%) & $19 / 59 / 11 / 11$ \\
\hline Choptank, Maryland & 1,042 (headwater) & 49 & Flat slopes $(<2 \%)$ & $18 / 24 / 16 / 42$ \\
\hline Upper Snake Rock, Idaho & 1,136 & 76 & Flat slopes $(<2 \%)$ & $0 / 4 / 64 / 32$ \\
\hline South Fork of lowa River, lowa & 785 & 84 & Flat slopes $(<2 \%)$ & $1 / 28 / 14 / 57$ \\
\hline Walnut Creek, lowa & 50 & 79 & Flat slopes $(<2 \%)$ & $0 / 34 / 7 / 59$ \\
\hline Upper Big Walnut Creek, Ohio & 491 & 44 & Flat slopes $(<2 \%)$ & $0 / 2 / 14 / 84$ \\
\hline Cedar Creek, Indiana & 710 & 63 & Mixed slopes & $5 / 6 / 8 / 81$ \\
\hline $\begin{array}{l}\text { Little River Experimental } \\
\text { Watershed, Georgia }\end{array}$ & 334 & 55 & Mixed slopes & $7 / 57 / 12 / 24$ \\
\hline
\end{tabular}


grains and, for dairy operations, alfalfa (Medicago sativa L.) (mixed alfalfa-grass) (Veith et al. 2015). Slopes in the cultivated portions of WE-38 ranged from $0 \%$ to $18 \%$, with a few woodland hillslopes approaching 32\% (Bryant et al. 2011). Hydrologic soil groups A through D were present, but group B was dominant. Soils having shallow restrictive layers were common in the lower portions of the landscape.

Flat Slopes. The Delta Water Management Research Unit, hereafter referred to as Delta Water, in northeast Arkansas, included the Little River Ditches basin in Mississippi County and the Lower St. Francis basin in Poinsett County. Both areas were predominantly agricultural; however, the cropping systems differed significantly as mostly rice (Oryza sativa L.) was grown in the Lower St. Francis and cotton (Gossypium hirsutum L.), corn, or soybean were grown in the Little River Ditches basin (Aryal and Reba 2017). The studied areas were part of an ongoing field-level study of the larger state-wide Mississippi River Basin Healthy Watersheds Initiative (MRBI) network (Reba et al. 2013) and included six different sites: Caraway, Leachville, Manila, Burdette Zero Grade, Burdette Precision Level, and Marked Tree, ranging in size from 0.07 to $0.3 \mathrm{~km}^{2}$. All fields in this watershed were very flat, with slopes ranging from $0 \%$ to $1 \%$. Each site was split into a control and a treatment field with monitoring equipment installed in each treatment to evaluate the effects of specific agricultural best management practices (BMPs) to reduce losses of nutrients ( $\mathrm{N}$ and $\mathrm{P})$ and sediment in the runoff water.

The Choptank River watershed (headwater 1,042 $\mathrm{km}^{2}$ ) in Maryland was impaired by excessive nutrient and sediment loads from agricultural land (McCarty et al. 2008). Land use in the watershed was dominated by agricultural land (65\%), forests (26\%), and developed areas (5\%) (Fisher et al. 2006). Almost $70 \%$ of the watershed had slope less than $2 \%$. This watershed had variation in the hydrologic soil group, the dominant one being hydrologic soil group D, followed by hydrologic soil group B. Even though Lee et al. (2018) evaluated suitability of the SVI in identifying inherent vulnerability to $\mathrm{NO}_{3}$ and organic $\mathrm{N}$ transport in two subwatersheds of the Choptank basin, results were included here as part of the overall synthesis across all the studied watersheds.
The Upper Snake Rock 8-digit hydrologic unit code (HUC) was $6,300 \mathrm{~km}^{2}$ with $60 \%$ range and forest land, and $37 \%$ irrigated cropland. This project focused on the Twin Falls irrigation project $\left(1,136 \mathrm{~km}^{2}\right)$, which was $80 \%$ irrigated cropland, $10 \%$ developed (urban or subdivision), and the remainder was open water, roads, or fallow. The study area was dominated by flat slopes and hydrologic soil group C and D. Large canals were used to supply water from the Snake River to irrigate cropland and pastures. Irrigationinduced soil erosion was a common environmental concern in the Upper Snake Rock watershed (Bjorneberg et al. 2008).

The Goodwin Creek watershed was 21 $\mathrm{km}^{2}$ in area and had mixed land use and management practices that influenced sediment loss to the streams (Alonso and Bingner 2000). There was substantial gullying, and gullied land, mostly silty, were reported for nearly a quarter of the watershed. The hydrologic soil groups ranged from A to D, with edge-of-field gauges sampling mostly areas with hydrologic soil group C soils. A key characteristic of this watershed was the large sediment loads generated by stream channel erosion. Croplands include only $6 \%$ of the watershed, and almost $80 \%$ of the croplands are in flat slopes.

The Beasley Lake watershed was a $6 \mathrm{~km}^{2}$ oxbow lake watershed with no contributing streams in the Lower Mississippi River Basin. The cropping system has transitioned from predominantly conventionally tilled cotton to predominantly conservation tillage soybean in 2002, and approximately $14 \%$ of the watershed was subsequently converted to Conservation Reserve Program (CRP, USDA Farm Service Agency) in 2003 (Lizotte et al. 2017). The site was dominated by hydrologic soil group C and D soils in undrained conditions. Slope was flat $(<2 \%)$ in most fields, and drainage ditches were used to transfer water from fields to the oxbow lake.

The South Fork of Iowa River watershed $\left(785 \mathrm{~km}^{2}\right)$ and the Walnut Creek watershed $\left(50 \mathrm{~km}^{2}\right)$ were poorly drained flat watersheds in Upper Mississippi River Basin in Iowa. Corn and soybean were the dominant crops in the South Fork of Iowa River watershed, grown annually in $85 \%$ of the watershed. Pasture covered $6 \%$ of the watershed. Highly erodible land covered $13 \%$ of the watershed area (Tomer and James 2004). The Walnut Creek watershed was predom- inantly under row crop production with corn and soybean rotation accounting for $80 \%$ of the land use (Hatfield et al. 1999). Soil wetness was a key concern for agriculture due to dominant $\mathrm{D}$ soils, so tile drainage was common in both watersheds.

The Upper Big Walnut Creek watershed, approximately $491 \mathrm{~km}^{2}$, was located in central Ohio. Almost $50 \%$ of the watershed had slope less than $2 \%$. Cropland for production agriculture was the dominant land use (73\%) in the watershed, followed by urban/farmstead (21\%) and woodland (6\%) (Williams et al. 2015). The primary crops grown were corn, soybean, and wheat (Triticum aestivum L.) managed with conservation tillage, fertilizer, and pesticide applications (King et al. 2008). There was an extensive network of subsurface tile drainage in this watershed. More than $75 \%$ of agricultural cropland in the watershed was tile drained.

Mixed Slopes. The Cedar Creek watershed $\left(710 \mathrm{~km}^{2}\right)$ was characterized by soils with slow permeability and small closed depressions or "potholes" that were scattered throughout the landscape. The closed depressions and poorly drained fields were often too wet to farm and required the use of artificial drainage to remove excess water during the growing season. While the extent of subsurface tile drainage and the number of surface inlets in Cedar Creek watershed were unknown, it was estimated that the vast majority $(>80 \%)$ of agricultural fields with poorly drained soils had artificial drainage. Almost $40 \%$ of the watershed had $<2 \%$ slope, $30 \%$ of the watershed had between $2 \%$ to $4 \%$ slope, and the remainder had $>4 \%$ slope.

The Little River Experimental Watershed $\left(334 \mathrm{~km}^{2}\right)$ had broad floodplains and mostly sandy soils. Most slopes were less than $5 \%$, with some valley side slopes ranging from $5 \%$ to $15 \%$ (Bosch et al. 2007). Land use in the watershed included agriculture (31\%), pasture $(10 \%)$, riparian forest $(28 \%)$, upland forest $(22 \%)$, and urban area $(7 \%)$ (Sullivan et al. 2008). The primary crops grown were row crops (cotton, corn, and peanut [Arachis hypogea L.]), and vegetables, typically without artificial drainage.

The Riesel USDA Agricultural Research Service (ARS) $\left(3.3 \mathrm{~km}^{2}\right)$ site in Texas, originally known as the Blackland Experimental Watershed, was dominated by poorly drained soils (hydrologic soil group D), and $>70 \%$ of the watershed had slope $<3 \%$. It included multiple cultivated watersheds and pasture 
watersheds. Major land use in the watershed included pasture and rangeland, and cropland producing corn, grain sorghum (Sorghum biocolor L. Moench), and oat (Avena sativa L.) (Harmel et al. 2000).

The Mark Twain Lake/Salt River basin watershed was located in northeast Missouri and included 10 subwatersheds (North Fork, Middle Fork, Elk Fork, Long Branch, South Fork, Lick Creek, Black Creek, Crooked Creek, Otter Creek, and Ely Creek) ranging in size from 271 to $1,579 \mathrm{~km}^{2}$. The basin had predominantly poorly drained claypan soils (hydrologic soil group D), which had characteristically high soil runoff potential. Dominant land use type included cropland (44\%), pasture (33\%), and forest (18\%) (Lerch et al. 2008). While the watershed had a range of slopes, the cropland was mostly located on land with $<4 \%$ slope. The Mark Twain Lake watershed and Riesel ARS sites were dominated by poorly drained D soils.

SVI Calculation and Evaluation. Thompson et al. (2020) describe the goals of the SVI, as well as the assumptions made and the methods employed to develop vulnerability classes and characterize them in terms of SSURGO parameters (tables 2 and $3)$. The runoff component of the SVI indirectly addresses the vulnerability of cropland to soil degradation and transport of nutrients via surface runoff. The leaching component of the SVI addresses the vulnerability of cropland to leaching. For this study, the SVI was calculated using ArcGIS software (version 10.3) using easily available input parameters from the SSURGO database and a DEM, and was applicable at scales ranging from a single field to a watershed. The SVI runoff component considers the hydrologic soil group, slope, and soil erodibility K-factor; while the SVI leaching component considers the same three properties plus the coarse fragment content of the soil and the presence of organic soils. A SSURGO soil layer was downloaded from the web soil survey (WSS) website (http://websoilsurvey.nrcs. usda.gov/app/HomePage.htm), and DEMs were obtained from the US Geological Survey (USGS) website (https://viewer. nationalmap.gov/launch/). Locally surveyed soil maps or properties or high resolution DEMs $(10 \mathrm{~m})$ were used when available. The soil layer was used to extract separate raster layers $(10 \mathrm{~m}$ resolution) for organic soil, hydrologic soil group, and USLE soil erodibility K-factor. Slope was computed from
DEMs by calculating the rate of maximum change in elevation across the eight adjacent neighbors in a 3-by-3 window (Gesch et al. 2002). The raster layers (organic soil, hydrologic soil, and soil erodibility $\mathrm{K}$-factor) were then combined cell-by-cell with the DEMderived slope layer in the raster calculator to derive both runoff and leaching components of the SVI based on the criteria for the four vulnerability classes. The SVI was calculated for every cell of the highest resolution input raster to create maps and summary tables, which were then discussed with scientists, hydrologists, and engineers from each study watershed via conference calls (included as coauthors in this article).

For soils that had a dual hydrologic soil group classification, the hydrologic soil group for undrained conditions was used per the SVI definition. In the Little River watershed, several soils were ambiguously classified within SSURGO reports, and in Goodwin Creek watershed, large gullied areas had no designated hydrologic soil group. Local scientists defined missing parameters for these soils and gullied areas. The leaching component of the SVI determined whether a soil is organic or not based on description for the Histosols and Histic epipedons (typically in the A horizon) in the SSURGO/ gSSURGO soil taxonomy.

The original method for SVI calculation was to use the SSURGO soil map unit representative slope. Chan et al. (2017) showed that this method resulted in an underestimation of the erosion vulnerability estimated by the SVI in Goodwater Creek Experimental Watershed. Analysis of aerial imagery showed that some of the areas not identified as having a high vulnerability when using the SSURGO slope were showing signs of severe soil degradation (presence of rills). In this study, DEM rather than SSURGO was used to determine slopes.

In watersheds with artificial drainage (tile or ditch), the SVI calls for increasing the leaching vulnerability by two classes (moderate and moderately high increased to high, and low increased to moderately high) (table 3). However, for this analysis, the initial classification of the leaching component of the SVI before artificial drainage was analyzed in order to be consistent with the other watersheds. This paper was intended to evaluate the effects of inherent soil properties separately from artificial drainage. A separate article analyzes the suitability of the SVI specifically for artificially drained cropland (Baffaut et al. 2020).

Scientists who participated in the SVI evaluations interpreted the results based on their knowledge of vulnerability and conservation needs in their respective watershed. Did the SVI vulnerability across the watershed correspond to the relative risks of pollutant transport by runoff and leaching in these fields? Was the SVI useful to assess conservation needs in the watersheds (i.e., was the SVI able to identify land that needed conservation practices before being used to grow crops)? Finally, was it helpful to decide where to focus conservation or planning efforts? Answers to the first two questions relied primarily on knowledge of the watershed. Answers to the last question relied on whether the distributions of vulnerability to runoff and leaching spanned the four classes or were skewed toward one or two classes. In the latter case, the index would be less useful to plan conservation.

Effect of Slope and Hydrologic Soil Group on SVI Distribution. Prior SVI validation results (Chan et al. 2017) showed a strong impact of slope on the SVI. Given that the definition of vulnerability to runoff gives an important role to slope, and to hydrologic soil group for the leaching component, it was important to consider to what extent slope and hydrologic soil group were the major drivers in these watersheds. The effects of slope on the runoff component of the SVI and of hydrologic soil group on the leaching component were considered across all the CEAP sites in this analysis. Linear regression analysis between the fractions of watershed in each SVI category and the fractions of watershed in each slope category for the runoff component, and in each hydrologic soil group for the leaching component, were conducted. In each case, the coefficient of determination $\left(r^{2}\right)$ and the regression slope were determined using Excel (Microsoft, Redmond, Washington) and its statistical package. Significance of the coefficient of determination and of the slope were assessed at the 0.05 probability. For analysis of vulnerability to runoff, the sites were grouped based on the three slope categories presented earlier (table 1) — steep slopes, flat slopes, and mixed slopes. The Mark Twain Lake watershed and Riesel ARS sites were separately analyzed because they also represented areas dominated by a single hydrologic soil group (i.e., poorly drained D soils). 
Table 2

Criteria for four classes of soil runoff potential (USDA NRCS 2016).

\begin{tabular}{lllll}
\hline $\begin{array}{l}\text { Soil runoff } \\
\text { potential }\end{array}$ & Hydrologic soil group & C & D \\
\cline { 2 - 5 } & A & B & Slope $<2$ & Slope $<2 ;$ K-factor $+<0.28$ \\
Low & All area & Slope $*<$ & $2 \leq$ slope $\leq 6$; K-factor $<0.28$ & Slope $<2 ;$ K-factor $\geq 0.28$ \\
Moderate & None & $4 \leq$ slope $\leq 6 ;$ K-factor $<0.32$ & $2 \leq$ slope $\leq 6 ;$ K-factor $\geq 0.28$ & $2 \leq$ slope $\leq 4$ \\
Moderately high & None & $4 \leq$ slope $\leq 6 ;$ K-factor $\geq 0.32$ & Slope $>4$ \\
High & None & Slope $>6$ & Slope $>6$ & \\
\hline
\end{tabular}

*Slope measured as percentage.

†K-factor refers to the soil erodibility factor $(\mathrm{K})$ found in the Universal Soil Loss Equation.

Table 3

Criteria for four classes of soil leaching potential (USDA NRCS 2016).

\begin{tabular}{|c|c|c|c|c|}
\hline \multirow{2}{*}{$\begin{array}{l}\text { Soil leaching } \\
\text { potential*† }\end{array}$} & \multicolumn{4}{|l|}{ Hydrologic soil group } \\
\hline & $\overline{\mathbf{A}}$ & B & $\mathbf{C}$ & $\mathbf{D}$ \\
\hline Low & None & None & None & All except organic soils \\
\hline Moderately high & Slope $>12$ & $3 \leq$ slope $\leq 12$ and $\mathrm{K}$-factor $<0.24$ & None & None \\
\hline High & $\begin{array}{l}\text { Slope } \leq 12 \text { or soils } \\
\text { classified as organic }\end{array}$ & $\begin{array}{l}\text { Slope }<3 \text { and } \mathrm{K} \text {-factor }<0.24 \\
\text { or soils classified as organic }\end{array}$ & Soils classified as organic & $\begin{array}{l}\text { Soils classified as } \\
\text { organic }\end{array}$ \\
\hline
\end{tabular}

*If the coarse fragment content of the soil is greater than $30 \%$ by weight, the soil leaching potential is increased by two levels (moderate and moderately high increased to high, and low increased to moderately high). If the coarse fragment content is greater than $10 \%$ but less than $30 \%$, the soil leaching potential is increased one level.

†Artificial drainage of any type increases leaching potential by two classes (moderate and moderately high increases to high, and low increases to moderately high).

$\ddagger \mathrm{K}$-factor refers to the soil erodibility factor $(\mathrm{K})$ found in the Universal Soil Loss Equation.

Another alternative is to calculate a representative slope for each soil map unit based on the fraction of that map unit within the study area. In essence, the slope is calculated as the average (mean, median, or 75 th percentile) cell value of an unfilled (i.e., unconditioned) DEM. This SVI calculation method was incorporated in the Agricultural Conservation Planning Framework (ACPF) tool, a set of custom-developed agricultural conservation planning tools at watershed scale (HUC12 watersheds), developed to be used with ArcGIS software (Tomer et al. 2013). These tools can be used to generate detailed maps that identify areas where different conservation practices can be located. The SVI results using ACPF-calculated slope were compared with SVI results using cellby-cell calculated slope for all 13 sites. Three means of calculating a representative slope for the map unit using ACPF were considered: 75 th percentile slope, mean slope, and median slope.

The hydrologic soil group is primarily determined based on the rate of infiltration in soils of different textures (USDA NRCS 2007), which decreases from hydrologic soil group A to D, and the presence of a restric- tive layer or water table within the first $50 \mathrm{~cm}$ of soils, which increases saturation excess runoff. The SVI leaching potential is derived from the infiltration rate and the natural drainage characteristics. For analysis of vulnerability to leaching, the sites were grouped based on the proportion of hydrologic group B soils in the croplands in the watershed. Sites with high proportion $(>50 \%)$ of B soils were WE-38 and Little River; Goodwin Creek, Choptank, South Fork of Iowa River, and Walnut Creek had proportion of B soils between $20 \%$ to $50 \%$; and sites with low proportion $(<20 \%)$ of B soils were Riesel, Mark Twain Lake, Delta sites, Upper Snake Rock, Beasley, Upper Big Walnut Creek, and Cedar. The different fields of the Water Management Research Center in Arkansas and the subwatersheds in the Mark Twain Lake were considered subsets of each site. To not bias the analysis by the conditions at these two sites, an areaweighted average of the fractions in each slope category, hydrologic soil group, and SVI category were calculated.

Effect of Digital Elevation Model Resolution on SVI Distribution. Multiple studies have shown the importance of
DEM for land use planners (Hammer et al. 1991), and the impact of DEM resolution on the outcomes from water quality models (Beeson et al. 2014). Since slope calculated from a DEM was used in this study instead of the SSURGO map unit representative slope, sensitivity to DEM resolution was conducted for all 13 watersheds. For each watershed and each SVI vulnerability category, differences between percentages of cropland area in each watershed obtained with each of three DEM resolutions $(30 \mathrm{~m}, 10 \mathrm{~m}$, and a fine resolution ranging from $1 \mathrm{~m}$ to $5 \mathrm{~m}$ ) were calculated. Results were considered significantly affected by DEM resolution if the percentage of cropland area differed by $5 \%$ or more for at least one vulnerability category.

Comparison with Model Outputs. Independent analyses have compared the SVI to modeling results in the Goodwater Creek Experimental Watershed (Chan et al. 2017), which is a watershed within the Mark Twain Lake watershed; Tuckahoe Creek and Greensboro watersheds (Lee et al. 2018), which are within the Choptank River watershed; and Goodwin Creek and Beasley Lake watersheds (Yasarer et al. 2020). In each case, a calibrated model was used to 
simulate sediment or nutrient transport by runoff or leaching. Since the SVI does not consider management, the model used a single management system appropriate for each watershed on all cropland. Edge-of-field simulated sediment and nutrient transport by runoff and leaching were classified into four classes. Since the studies were independent, they did not use the same thresholds to define vulnerability classes based on model outputs. Yasarer et al. (2020) considered sediment losses and used the thresholds established during the development of the SVI (Thompson et al. 2020). In contrast, Chan et al. (2017) and Lee et al. (2018) used the Jenks natural break method (Jenks 1967) to divide model outputs for spatial units into four classes (high, moderately high, moderate, and low). This method minimizes the variance within each group and maximizes the variance between groups (Jenks 1967).

Simultaneously, the SVI was assessed for the spatially defined cells or units defined by the model using the soil and topographic inputs of the model. The synthesis of these three studies considered two aspects. First, the median values of simulated soil loss and nutrient yields and the SVI vulnerability class should be consistent, meaning distinct and increasing median values for increasing vulnerability. Second, classification by either method should be similar. The similarity rate (i.e., the areal proportion of cropland classified in the same vulnerability class by the SVI and using model outputs) was deemed good if greater than $75 \%$, the criterion used for a good match between model results and SVI classification during SVI development (Thompson et al. 2020). Additionally, the similarity was deemed acceptable if the similarity rate was greater than $65 \%$. In each case, the SVI component used for the comparison was the main pathway for the transport of each constituent: the runoff component for contaminants transported via surface runoff (i.e., sediment, total $\mathrm{N}$, and organic $\mathrm{N}$ ), and the leaching component for $\mathrm{NO}_{3}$, which are transported via leaching.

\section{Results and Discussion}

Figure 2 shows the SVI vulnerability to runoff in the study sites. The overall SVI calculation was easy to perform with a basic knowledge of ArcGIS software. The input data required for SVI assessment were all publicly available for these US sites. Based on the responses from the local scientists, the
SVI was useful for conservation effort targeting in some watersheds and not so useful in others. The relationship between the SVI and slope or soil hydrologic group helped clarify when the SVI was useful or not. Areas with mixed slopes and hydrologic soil groups showed a range of SVI vulnerability, thus providing potential to identify locations where efforts need to focus. In contrast, areas with uniform slope and hydrologic soil group showed uniform SVI vulnerability class such that the SVI was not able to distinguish fields that were more or less vulnerable than others. The following sections describe the impact of slope and hydrologic group distribution on the results and usefulness of the index.

Effect of Slope on SVI Vulnerability to Runoff. Results of the regression between proportions of land in each slope category and in each SVI category are shown in table 4. In many cases, there was a significant relationship between slope category and SVI class. However, there were some exceptions. We provide more details in the following paragraphs.

Slope was the dominant factor for the runoff component of the SVI in watersheds where steep slopes $(>6 \%)$ were prevalent (WE-38; figure 2). When slope was steep, the corresponding vulnerability to runoff was always high (table 2) regardless of hydrologic soil group and K-factor. Thus, the relationship between fractions of the watershed in each slope category and each class of the runoff component of the SVI was very strong, and the slope distribution explained $95 \%$ or more of the variability in vulnerability to runoff (table 4). Yet this was likely an artifact of the $r^{2}$ coefficient of determination, which is biased toward high values. While this is correct given the high slopes, SVI indication of vulnerability was not particularly useful. Hillslopes with $>6 \%$ slope may be consistently and rightfully considered the most vulnerable to runoff, but the SVI was not able to differentiate the greatest problem areas and prioritize efforts, in case of limited resources, for example. Cultivated areas with high vulnerability to runoff in the lower section of WE-38 would benefit from other relevant information such as landscape position (Buda et al. 2009a; Needelman et al. 2001, 2004) and presence of a restrictive layer (Buda et al. 2009b; Gburek et al. 2006), which affect runoff and thus erosion vulnerability.
In watersheds with flat slopes $(<2 \%)$, the only factors that could affect the runoff component of the SVI was the hydrologic soil group and the $\mathrm{K}$-factor value relative to the 0.28 threshold. However, all these watersheds had large proportions of hydrological soil group D soils and, in most cases, the K-factor was $<0.28$, which resulted in equal and large fractions of land with low slopes and low vulnerability to runoff, and consequently high values of $r^{2}$ between fractions of watershed (or cropland) in each slope and SVI category (table 4). All the watersheds with flat slopes and poorly drained soils were artificially drained.Vulnerability to leaching was therefore raised by two classes, thus compressing four classes into two classes. Baffaut et al. (2020) made a separate evaluation of the SVI in the presence of artificial drainage, which brings additional complexity for the leaching component (per SVI definition, table 3), but also for the runoff component. In Goodwin, the lack of discernment of the SVI may not be as important because the vulnerability to runoff was recognized, and most of the highly vulnerable land went out of cultivation at the dawn of the twenty-first century. However, if it was cropped, as it had been in the nineteenth until the mid-twentieth century, gully formation and sheet erosion would increase as historical pictures demonstrate (Kuhnle et al. 1996; Wilson et al. 2015). Other parameters such as clay content have been successful predictors of the susceptibility to gully erosion (Grissinger and Murphey 1989).

For watersheds with mixed slopes (Cedar Creek and Little River), the vulnerability to runoff was affected by the two other factors: hydrologic soil group and $\mathrm{K}$-factor. The resulting relationship between fractions of watershed in each slope category and each SVI category was weak $\left(r^{2}=0.024\right)$, and the regression slope was not significantly different from 0 (table 4). Incidentally, it is in these watersheds that scientists agreed most with the SVI outcomes, finding that vulnerability to runoff was well described by the SVI.

Both Mark Twain Lake and Riesel were representative of mixed slopes but were dominated by a single hydrologic soil group (D; table 1) and K-factors $>0.28$. Definitions of SVI given in table 2 implied that soils in the lowest slope category had a moderate vulnerability due to runoff, those with $2 \%$ to $4 \%$ slope had a moderately high vulnerability, and everything with $>4 \%$ slope had a high vulnerability due to runoff. Since the 


\section{Figure 2}

Soil Vulnerability Index (SVI) runoff potential for 13 sites.

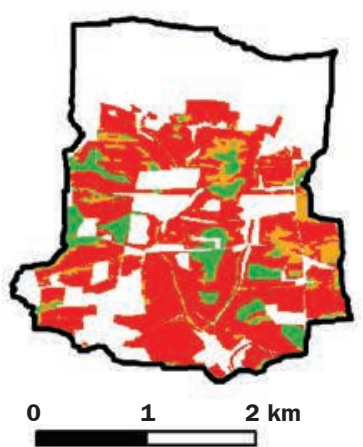

WE-38

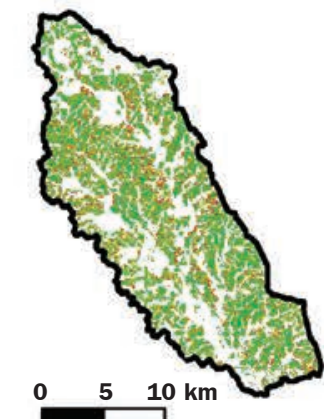

Little River

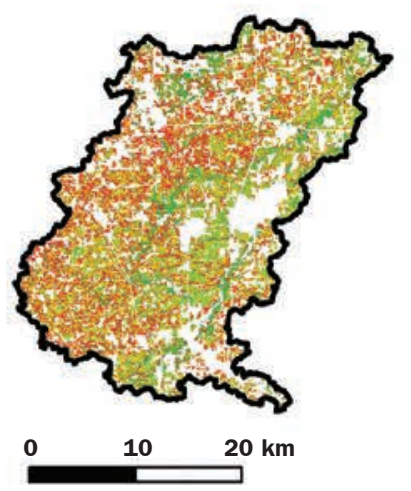

Cedar Creek

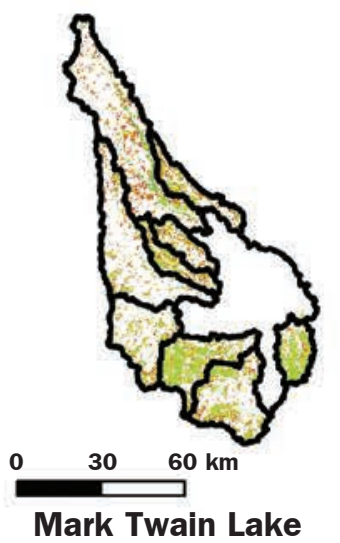

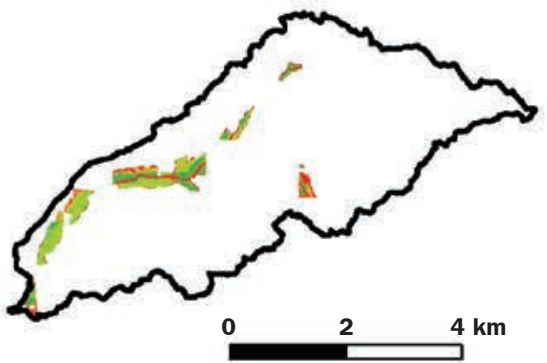

Goodwin Creek

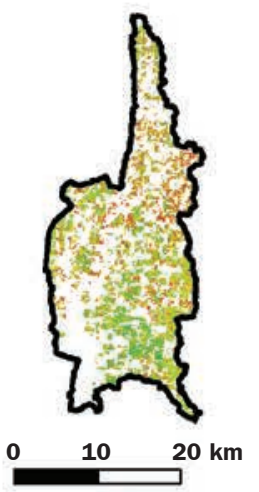

Upper Big Walnut Creek
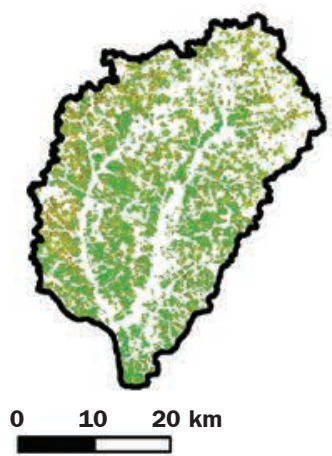

Choptank

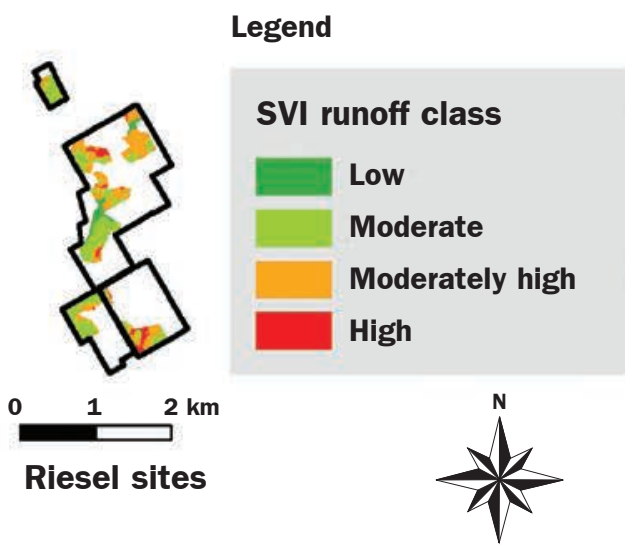

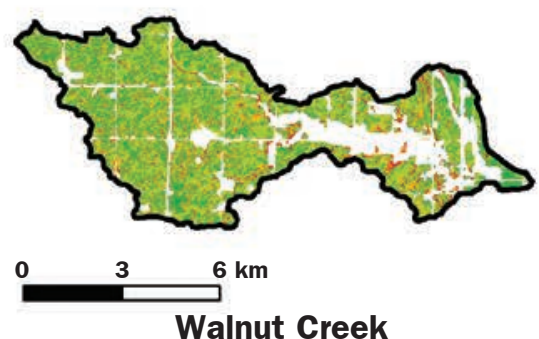

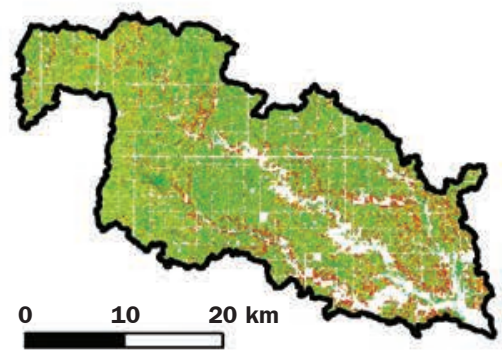

South Fork of lowa River

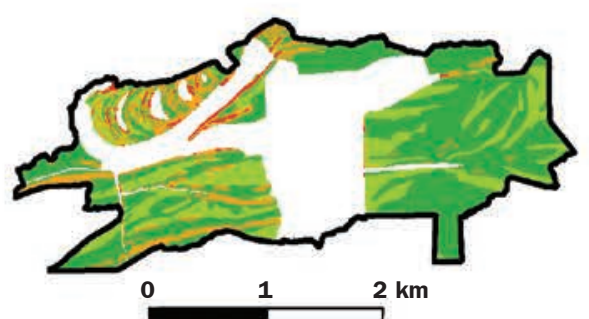

Beasley Lake

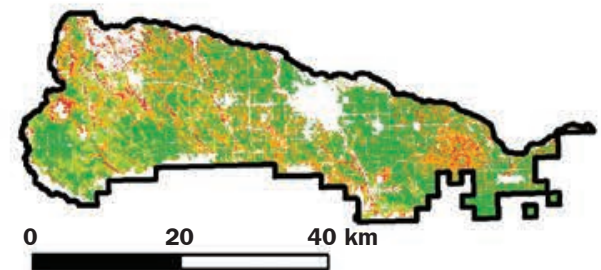

Upper Snake Rock
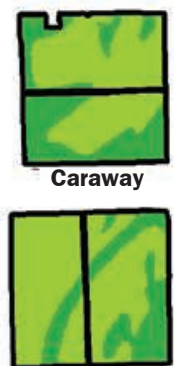

Burdette PL
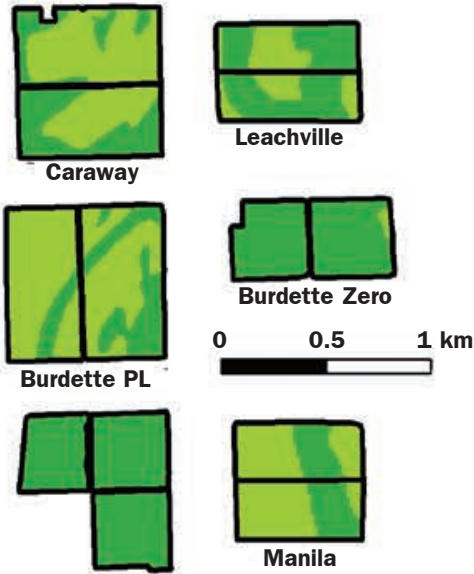

Marked Tree Delta Water fields 


\section{Table 4}

Relationship between the fractions of watershed in each slope category (10 $\mathrm{m}$ digital elevation model [DEM]) and in each category of the runoff component of the Soil Vulnerability Index (SVI); and the fractions of watershed in each hydrologic soil group (HSG) category and each category of the SVI leaching component using a $10 \mathrm{~m}$ DEM.

\begin{tabular}{|c|c|c|c|c|c|}
\hline Slope/HSG category & Number of sites & $\begin{array}{l}\text { Number of } \\
\text { data points }\end{array}$ & $r^{2}$ & Regression slope & $\begin{array}{l}\text { Standard error of } \\
\text { regression slope }\end{array}$ \\
\hline \multicolumn{6}{|l|}{ Dominant slope condition } \\
\hline Steep slopes & 1 & 4 & $0.95 * *$ & $0.90 * *$ & 0.15 \\
\hline $\begin{array}{l}\text { Flat slopes, } \\
\text { artificial drainage }\end{array}$ & 8 & 28 & $0.68 * *$ & $0.54 * *$ & 0.07 \\
\hline Mixed slopes & 2 & 8 & 0.02 & 0.18 & 0.54 \\
\hline $\begin{array}{l}\text { Mixed slopes (uniform } \\
\text { hydrologic soil group) }\end{array}$ & 2 & 6 & $0.98 * *$ & $0.90 * *$ & 0.06 \\
\hline All watersheds & 13 & 50 & $0.38 * *$ & $0.48 * *$ & 0.09 \\
\hline \multicolumn{6}{|l|}{ Fraction of HSG B soils } \\
\hline High (>50\%) & 2 & 8 & 0.14 & -0.44 & 0.44 \\
\hline Moderate (20\% to $50 \%)$ & 4 & 16 & 0.21 & 0.54 & 0.28 \\
\hline Low $(<20 \%)$ & 7 & 26 & $0.99 * *$ & $0.99 * *$ & 0.02 \\
\hline All watersheds & 13 & 50 & $0.50 * *$ & $0.74 * *$ & 0.11 \\
\hline
\end{tabular}

**Indicates significance at the 0.05 level of the slope or coefficient of determination at the 0.05 level.

hydrologic soil group and the K-factor were uniform across these two watersheds, the only factor controlling risk of degradation by runoff as indicated by the SVI was the slope. This was confirmed by aerial photos showing signs of soil degradation or presence of terraces on the steepest cropped land (Chan et al. 2017). However, rills have also been observed on areas with $<2 \%$ slope in Mark Twain Lake watershed where the argillic horizon was close to the surface $(<10 \mathrm{~cm})$, a sign of vulnerability to soil erosion linked to concentrated flow. These were observed in no-till areas, i.e., where a conservation practice to limit soil erosion had already been implemented but was not sufficient to prevent degradation. They certainly also occurred on tilled areas, but tillage regularly erased them. With a low or moderate SVI vulnerability to runoff, the need for conservation measures may be overlooked. Additional information may provide the missing information to describe accurately the vulnerability to runoff under these very vulnerable conditions. For example, landscape features such as slope length (Chaplot and Bissonnais 2003; Jamison and Peters 1967), depth to a restrictive layer (Buda et al. 2009b; Gburek et al. 2006), depth to claypan (Chan et al. 2017), spatial scale of landscape pattern change over distance (Fiener et al. 2011), or landscape dissecting features that disrupt runoff energies (Jencso and McGlynn 2011) have been shown to increase vulnerability to runoff.

Results from the SVI tool within the ACPF framework varied depending on the dominant slope of the site (table 5). Results were examined with regards to the slope class breaks used for calculating the SVI. If the range of slope metrics by map unit did not cross a SVI class threshold (for example, low relief landscapes with dominant steep or flat slopes), the resulting SVI class distribution did not alter substantially (table 5). Incorporating SVI tool into ACPF can thus provide flexibility in using the different slope preferences based on topographic parameters. When calculating the SVI within the ACPF, all the inputs were calculated on a map unit basis within the study area. As expected, calculating the SVI using an average cell DEM slope within each map unit reduced the variability of the SVI calculated using DEM-derived cell-by-cell slope determination (table 5). Doing so may bring consistency to a tool that was intended to be a reclassification of SSURGO soil map unit attributes. The flexibility of selecting one or several slope averaging methods seems to provide results close to those calculated on a cell-by-cell basis.

Effect of Hydrologic Soil Group on SVI Vulnerability to Leaching. Hydrologic soil group had a very strong impact on the leaching component of the SVI, and in many cases, the maps of hydrologic soil group and SVI vulnerability to leaching were exactly the same (Riesel, Mark Twain Lake, Delta Research Center fields, and Upper Big Walnut Creek) or very similar (Upper Snake Rock, Beasley, and Cedar Creek). The SVI leaching component changed with slope and soil erodibility $\mathrm{K}$-factor only for soils in the hydrologic soil group B. For soils in the hydrologic soil group A, slope was a factor (table 3), but amounts of A soils were too small in these watersheds, except WE-38, to assess the effect of slope on the SVI for these soils. Grouping watersheds based on their dominant slope characteristics was not as useful for the leaching component of the SVI as it was for the runoff component. Instead, the critical factor was the fraction of soils in hydrologic soil group B (table 4). For those with high proportions $(>50 \%)$ of hydrologic soil group B soils, the relationship between fractions of watershed in each hydrologic soil group and each SVI leaching vulnerability category was weak $\left(r^{2}=0.14\right.$; table 4$)$. In areas with more than $50 \%$ hydrologic soil group B, SVI leaching vulnerability changed with soil erodibility K-factor. For those with moderate proportions (20\% to $50 \%$ ) of hydrologic soil group B soils, the relationship between fractions of watershed in each hydrologic soil group and each SVI leaching vulnerability category was weak, but slightly better than watersheds with dominantly B soils $\left(r^{2}=0.21\right.$; table 4$)$. The other group of watersheds had low proportions of hydrologic soil group B soils ( $<20 \%)$, and for those, the hydrologic soil group was the main factor driving vulnerability to leaching $\left(r^{2}=0.99\right.$; table 4). In areas with hydrologic soil group $\mathrm{C}$ and D soils, the leaching component of the SVI changed only if the soil contained enough organic matter to be considered an organic soil. Only the Choptank watershed had soils with organic layers, which resulted in greater vulnerability to leaching, which is further discussed by Baffaut et al. (2020). 
Table 5

Comparison of Soil Vulnerability Index (SVI) classes distribution (\%) using cell-by-cell slope calculation with SVI distribution using the Agricultural Conservation Planning Framework (ACPF) tool.

\begin{tabular}{|c|c|c|c|c|c|}
\hline \multirow[b]{2}{*}{ Watershed } & \multirow[b]{2}{*}{ SVI class* } & \multirow{2}{*}{$\begin{array}{l}\text { SVI distribution (\%) } \\
\text { using cell-by-cell slope }\end{array}$} & \multicolumn{3}{|c|}{ SVI distribution (\%) using ACPF tool } \\
\hline & & & Mean slope & Median slope & 75th percentile slope \\
\hline \multirow[t]{3}{*}{ WE-38 } & $\mathrm{L}$ & 14 & 9 & 9 & 9 \\
\hline & $\mathrm{MH}$ & 12 & 0 & 0 & 0 \\
\hline & $\mathrm{H}$ & 74 & 86 & 66 & 91 \\
\hline \multirow[t]{2}{*}{ Delta } & $\mathrm{L}$ & 57 & 57 & 57 & 43 \\
\hline & $\mathrm{H}$ & 0 & 0 & 0 & 11 \\
\hline \multirow[t]{4}{*}{ Choptank } & $\mathrm{L}$ & 67 & 88 & 93 & 82 \\
\hline & $\mathrm{M}$ & 17 & 7 & 6 & 6 \\
\hline & $\mathrm{MH}$ & 12 & 5 & 1 & 11 \\
\hline & $\mathrm{H}$ & 4 & 0 & 0 & 1 \\
\hline Upper Snake Rock & $\mathrm{L}$ & 50 & 50 & 50 & 50 \\
\hline \multirow{3}{*}{ Goodwin } & $M$ & 39 & 0 & 43 & 0 \\
\hline & $\mathrm{MH}$ & 15 & 81 & 19 & 51 \\
\hline & $\mathrm{H}$ & 19 & 17 & 6 & 48 \\
\hline \multirow[t]{4}{*}{ Beasley } & $\mathrm{L}$ & 61 & 59 & 65 & 59 \\
\hline & $\mathrm{M}$ & 24 & 17 & 24 & 17 \\
\hline & $\mathrm{MH}$ & 13 & 19 & 11 & 19 \\
\hline & $\mathrm{H}$ & 2 & 5 & 0 & 5 \\
\hline \multirow{4}{*}{$\begin{array}{l}\text { South Fork } \\
\text { of lowa River }\end{array}$} & $\mathrm{L}$ & 38 & 44 & 44 & 44 \\
\hline & $M$ & 37 & 56 & 56 & 56 \\
\hline & $\mathrm{MH}$ & 17 & 0 & 0 & 0 \\
\hline & $\mathrm{H}$ & 8 & 0 & 0 & 0 \\
\hline \multirow[t]{4}{*}{ Cedar Creek } & $\mathrm{L}$ & 22 & 45 & 45 & 20 \\
\hline & $M$ & 23 & 54 & 55 & 16 \\
\hline & $\mathrm{MH}$ & 30 & 1 & 0 & 1 \\
\hline & $\mathrm{H}$ & 25 & 0 & 0 & 63 \\
\hline \multirow[t]{4}{*}{ Little River } & $\mathrm{L}$ & 65 & 63 & 64 & 27 \\
\hline & M & 21 & 23 & 24 & 55 \\
\hline & $\mathrm{MH}$ & 6 & 13 & 12 & 8 \\
\hline & $\mathrm{H}$ & 8 & 1 & 0 & 10 \\
\hline \multirow[t]{4}{*}{ Riesel } & $\mathrm{L}$ & 6 & 6 & 6 & 5 \\
\hline & $M$ & 48 & 0 & 49 & 0 \\
\hline & $\mathrm{MH}$ & 39 & 94 & 45 & 93 \\
\hline & $\mathrm{H}$ & 7 & 0 & 0 & 2 \\
\hline \multirow[t]{4}{*}{ Mark Twain Lake } & $\mathrm{L}$ & 0 & 0 & 0 & 0 \\
\hline & $M$ & 65 & 59 & 66 & 29 \\
\hline & $\mathrm{MH}$ & 24 & 31 & 27 & 51 \\
\hline & $\mathrm{H}$ & 11 & 10 & 7 & 20 \\
\hline
\end{tabular}


Effect of Digital Elevation Model Resolution on SVI Vulnerability to Runoff. Since the runoff component of the SVI was heavily dependent on slope for many of the watersheds, and since slope was calculated for each cell of the DEM, it was expected that DEM resolution would impact the results for that component of the SVI. As expected, DEM resolution did not affect the results for the leaching component. The SVI leaching component depended primarily on the hydrologic soil group, which is not affected by DEM resolution. For the runoff component, DEM resolution affected the SVI for croplands in 8 out of 13 watersheds when comparing the $10 \mathrm{~m}$ and $30 \mathrm{~m}$ DEM, which is almost $60 \%$ of the watersheds (table 6). Comparison of results obtained with the 10 $\mathrm{m}$ DEM and a finer resolution DEM (from 1 $\mathrm{m}$ to $5 \mathrm{~m}$ depending on availability) showed that croplands in 3 out of the 8 watersheds for which a fine resolution DEM did exist were affected. Watersheds for which a $10 \mathrm{~m}$ and a $30 \mathrm{~m}$ DEM did not affect SVI results included WE-38, Riesel, Upper Snake Rock, Little River, and Delta Water. For these (except WE-38), a high-resolution $(<10$ m) DEM was not available for assessment. For WE-38, SVI distribution was similar whether using a 30,10 , or $5 \mathrm{~m}$ DEM. This can be explained by the uniform topography in this watershed, which remains steep $(>6 \%)$ no matter the cell size from which slopes were calculated.

In watersheds with mixed slopes, high-resolution DEM permitted identifying short but steep slopes such as faces of terraces, gullies, stream banks, or banks along ditches, roads, and rivers as high vulnerability for runoff. Conversely, coarser DEM resolution resulted in increased fractions of watersheds in the lowest category of slopes and a decrease in the fraction of watersheds in the steepest slope categories (figure 3). Thus, there is a possibility that high vulnerability areas (with $>6 \%$ slope) that require attention could fail to be identified with a coarser DEM. While controlling erosion and nutrient inputs to the water body, steep banks along roads or railways may be of greater importance; however, on the other hand, those areas may need to be buffered for any cropland management program. Hence, masking out noncropped areas should be recommended, especially with fine scale assessments.

Table 6

Distributions of the runoff and leaching components of the Soil Vulnerability Index (SVI) as affected by digital elevation model (DEM) resolution.

\begin{tabular}{|c|c|c|c|c|}
\hline \multirow[b]{2}{*}{ Watershed } & \multirow[b]{2}{*}{ SVI class* } & \multicolumn{3}{|c|}{ Runoff component of SVI DEM resolution } \\
\hline & & High resolution $†$ & $10 \mathrm{~m}$ & $30 \mathrm{~m}$ \\
\hline \multirow[t]{4}{*}{ Goodwin Creek } & L & 28 & 27 & 35 \\
\hline & M & 37 & 39 & 37 \\
\hline & $\mathrm{MH}$ & 15 & 15 & 20 \\
\hline & $\mathrm{H}$ & 20 & 19 & 8 \\
\hline \multirow[t]{4}{*}{ Mark Twain Lake } & $\mathrm{L}$ & - & 1 & 1 \\
\hline & M & - & 61 & 64 \\
\hline & $\mathrm{MH}$ & - & 24 & 26 \\
\hline & $\mathrm{H}$ & - & 14 & 9 \\
\hline \multirow[t]{4}{*}{ Choptank } & $\mathrm{L}$ & 66 & 67 & 77 \\
\hline & M & 15 & 17 & 19 \\
\hline & $\mathrm{MH}$ & 14 & 12 & 4 \\
\hline & $\mathrm{H}$ & 5 & 4 & 0 \\
\hline \multirow[t]{4}{*}{ Beasley } & L & 52 & 61 & 66 \\
\hline & M & 21 & 24 & 27 \\
\hline & $\mathrm{MH}$ & 22 & 13 & 7 \\
\hline & $\mathrm{H}$ & 5 & 2 & 0 \\
\hline South Fork & L & 35 & 38 & 46 \\
\hline \multirow[t]{3}{*}{ of lowa River } & M & 36 & 37 & 39 \\
\hline & $\mathrm{MH}$ & 19 & 17 & 12 \\
\hline & $\mathrm{H}$ & 10 & 8 & 3 \\
\hline \multirow[t]{4}{*}{ Walnut Creek } & L & 36 & 39 & 44 \\
\hline & M & 36 & 38 & 43 \\
\hline & $\mathrm{MH}$ & 21 & 19 & 12 \\
\hline & $\mathrm{H}$ & 7 & 4 & 1 \\
\hline Upper Big & L & 15 & 17 & 20 \\
\hline \multirow[t]{3}{*}{ Walnut Creek } & M & 36 & 42 & 52 \\
\hline & $\mathrm{MH}$ & 33 & 31 & 24 \\
\hline & $\mathrm{H}$ & 16 & 10 & 4 \\
\hline \multirow[t]{3}{*}{ Cedar Creek } & L & 19 & 22 & 27 \\
\hline & M & 19 & 23 & 31 \\
\hline & $\begin{array}{l}\mathrm{MH} \\
\mathrm{H}\end{array}$ & 31 & 30 & 28 \\
\hline
\end{tabular}

* $\mathrm{L}=$ low, $\mathrm{M}=$ moderate, $\mathrm{MH}=$ moderately high, and $\mathrm{H}=$ high.

†The high resolution DEM was $1 \mathrm{~m}$ for Goodwin Creek watershed; $2 \mathrm{~m}$ for Choptank watershed, Cedar Creek watershed, Upper Big Walnut Creek, and Walnut Creek; $1.5 \mathrm{~m}$ for Beasley Lake watershed; and $3 \mathrm{~m}$ for South Fork of lowa River.

Optimal DEM resolution varied with lengths of the features that may cause problems. If gullies need to be identified, a resolution compatible with the width and length of these gullies is preferable. Finest DEM $(1 \mathrm{~m})$ in Goodwin Creek watershed was able to identify gullied areas as high vulnerability. Ditch bank erosion may be a significant problem in watersheds like Beasley Lake, and should not be buffered out when using a high-resolution DEM. For sites that have varying slopes across a topo-sequence, the SVI used in combination with a high-resolution DEM gives the ability to identify areas within a field that are of greater concern. While this may not have been the original intent of the SVI, conservation planning may benefit from the ability to identify those areas across a field.

Comparison with Model Outputs. Comparison results between land vulnerability assessed by the SVI and model results were inconsistent from watershed to watershed. In Goodwater Creek watershed (Chan 
et al. 2017), the ranges of constituent yields (sediment, total $\mathrm{N}$, and total $\mathrm{P}$ ) for the high, moderately high, and moderate vulnerability classes were distinct and consistent with SVI vulnerability classification (table 7). However, there was no clear differentiation between the total $\mathrm{N}$ and total $\mathrm{P}$ yields for the low and moderate SVI vulnerability classes. In the well-drained Tuckahoe watershed (Upper Choptank watershed), simulated $\mathrm{NO}_{3}$ yields in surface runoff and leachate (simulated leaching and $\mathrm{NO}_{3}$ transport by lateral flow) were inconsistent with SVI classification. Nitrate transported by runoff was smaller for areas with high SVI vulnerability than with low vulnerability (table 7). Average loss of organic $\mathrm{N}$, which is transported by surface runoff, was consistent with SVI ranking. In the poorly drained Greensboro watershed (also in the Upper Choptank watershed), simulated $\mathrm{NO}_{3}$ yields in surface runoff were inconsistent with SVI classification, while simulated organic $\mathrm{N}$ in runoff and leached $\mathrm{N}$ yields were consistent. However, there was no or little differentiation between the moderately high and high vulnerability class. Lee et al. (2018) concluded that SVI runoff classification scheme was suited for identifying critical source areas vulnerable to organic $\mathrm{N}$ in Greensboro, while the SVI leaching classification scheme was suited for $\mathrm{NO}_{3}$. In Beasley Lake watershed, sediment yields were not differentiable between SVI classes (table 7) except for the highest vulnerability class, and in Goodwin Creek watershed sediment yields differed only for the moderately high and high vulnerability classes.

Similarity rates between classification based on SVI and model results (table 8) confirmed the previous findings. Overall, similarity rates were good or acceptable when the processes matched the SVI component, but with some exceptions. In Goodwater Creek (Chan et al. 2017), surface runoff causes sediment and nutrient movement. Model based vulnerability was similar to vulnerability based on the runoff component of the SVI (table 8 ), and was consistent with the judgement of local scientists. In Greensboro, which is dominated by poorly drained soils and has an extensive and dense network of drainage ditches, vulnerability classification based on the leaching component of SVI and model results was similar for leached N. Similarly in Tuckahoe, which has well-drained soils and not as much artificial drainage, classification based on the runoff component of SVI and

\section{Figure 3}

Slope category ([a] $3 \mathrm{~m}$ digital elevation model [DEM], [b] $10 \mathrm{~m}$ DEM, and [c] $30 \mathrm{~m} \mathrm{DEM}$ ) for the runoff component of the Soil Vulnerability Index (SVI) in the croplands of the South Fork of lowa River.

\section{(a)}

3 m DEM

(b)

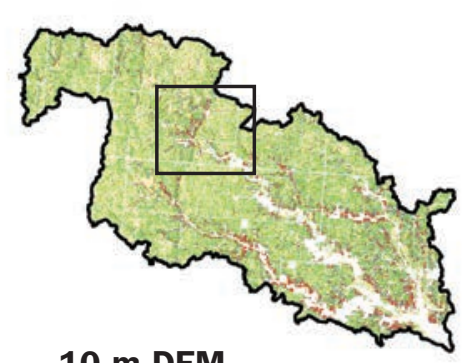

10 m DEM

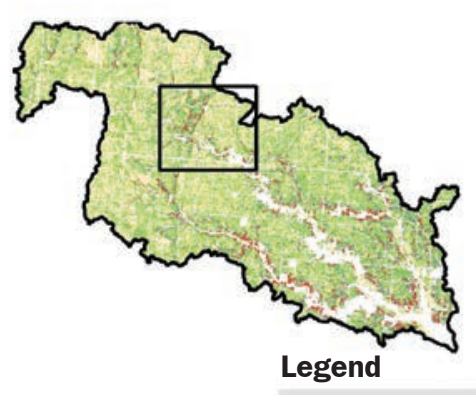

Slope (\%)

(c) $30 \mathrm{~m} \mathrm{DEM}$ $<2$

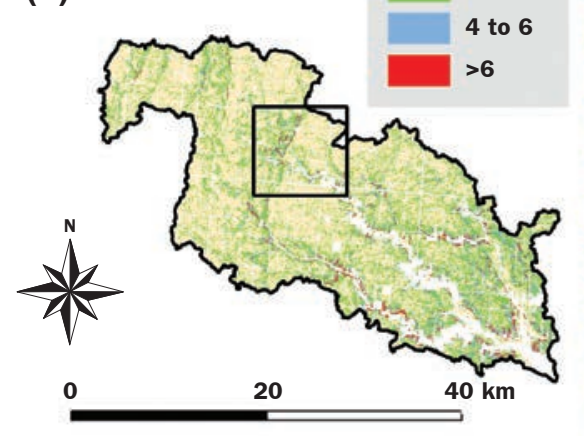

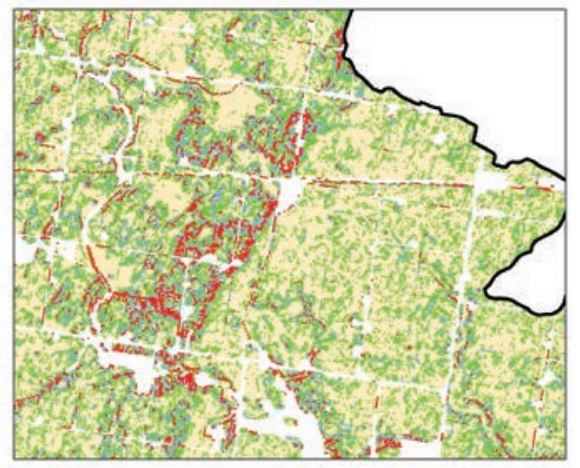
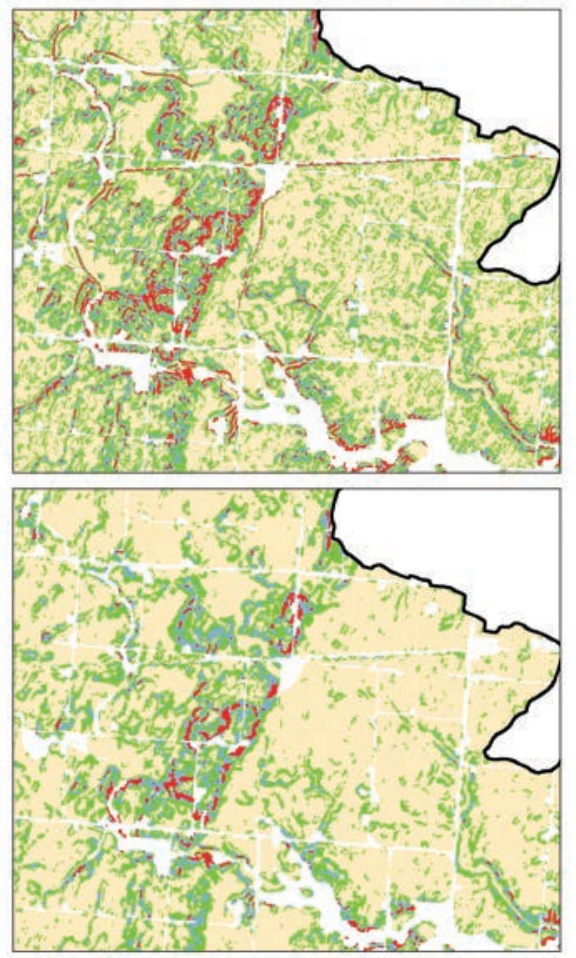

model results was similar for constituents transported by surface runoff. However, similarity was poor for leached constituents. Lee et al. (2018) attributed this poor similarity to varying soil water capacity across the watershed. In Beasley, which features drainage ditches around each field, similarity of SVI classification and simulated sediment yields, which are controlled by surface runoff processes, was poor. Similarity rate was better in Goodwin, but sediment yields were not fully consistent with SVI classification. Yet, land taken out of production in these two watersheds was land primarily classified with high vulnerability by the SVI, a confirmation of the potential for the SVI to identify high vulnerability areas. Overall, the models showed inconsistent results between SVI classification and average amounts of sediment or nutrients lost per unit area (tables 7 and 8).

\section{Summary and Conclusions}

The SVI was developed by the USDA NRCS CEAP to classify cropland vulnerability to runoff and leaching into four categorical classes-low, moderate, moderately high, and high. The SVI calculation required basic ArcGIS tools using easily available input parameters from the SSURGO database and a DEM, and was applicable at scales ranging from a single field to a watershed or region. In this study, SVI maps for 13 watersheds were generated and evaluated by scientists 
Table 7

Contaminant loads from hydrologic response units (HRUs) by vulnerability class determined with the Soil Vulnerability Index (SVI).

\begin{tabular}{|c|c|c|c|c|}
\hline \multirow[b]{2}{*}{ SVI category* } & \multicolumn{4}{|c|}{ Mean and standard deviation of contaminant load } \\
\hline & Low & Moderate & Moderately high & High \\
\hline \multicolumn{5}{|l|}{ Goodwater } \\
\hline Total $\mathrm{N}$ in surface flow $\left(\mathrm{kg} \mathrm{ha}^{-1}\right)$ & $9(1.7)$ & $11(2.2)$ & $15(0.5)$ & $22(1.3)$ \\
\hline Total $\mathrm{P}$ in surface flow $\left(\mathrm{kg} \mathrm{ha}^{-1}\right)$ & $0.7(0.2)$ & $1.1(0.3)$ & $1.7(0.1)$ & $2.9(0.2)$ \\
\hline Organic $\mathrm{N}$ in surface flow $\left(\mathrm{kg} \mathrm{ha}^{-1}\right)$ & $10.0(6.44)$ & $22.47(5.02)$ & $27.52(9.83)$ & $38.72(6.59)$ \\
\hline Leached N $\left(\mathrm{kg} \mathrm{ha}^{-1}\right)$ & $35.78(8.29)$ & $40.66(2.79)$ & $36.98(5.10)$ & $38.98(5.48)$ \\
\hline \multicolumn{5}{|l|}{ Greensboro } \\
\hline $\mathrm{NO}_{3}-\mathrm{N}$ in surface flow $\left(\mathrm{kg} \mathrm{ha}^{-1}\right)$ & $2.92(2.43)$ & $3.96(1.19)$ & $6.79(1.10)$ & $2.08(0.25)$ \\
\hline Organic $\mathrm{N}$ in surface flow $\left(\mathrm{kg} \mathrm{ha}^{-1}\right)$ & $21.40(10.22)$ & $32.23(5.40)$ & $43.26(11.81)$ & $44.58(3.67)$ \\
\hline \multicolumn{5}{|l|}{ Goodwin } \\
\hline Sediment in surface flow $\left(\mathrm{t} \mathrm{ha}^{-1}\right)$ & $7.4(2.5)$ & $7.5(0.67)$ & $13(11)$ & $40(44)$ \\
\hline \multicolumn{5}{|c|}{ Notes: $\mathrm{N}=$ nitrogen. $\mathrm{P}=$ phosphorus. $\mathrm{NO}_{3}=$ nitrate. } \\
\hline
\end{tabular}

\section{Table 8}

Similarity rate between vulnerability classification based on the Soil Vulnerability Index (SVI) and model outputs.

\begin{tabular}{|c|c|c|c|c|c|c|c|}
\hline \multirow[b]{2}{*}{ Watershed } & \multirow[b]{2}{*}{$\begin{array}{l}\text { Drainage } \\
\text { characteristics }\end{array}$} & \multirow[b]{2}{*}{$\begin{array}{l}\text { Model } \\
\text { used }\end{array}$} & \multicolumn{5}{|c|}{ Classification similarity rate (\%) } \\
\hline & & & $\begin{array}{l}\text { Surface runoff } \\
\text { sediment }\end{array}$ & $\begin{array}{l}\text { Surface runoff } \\
\text { total P }\end{array}$ & $\begin{array}{l}\text { Surface runoff } \\
\mathrm{NO}_{3}-\mathrm{N}\end{array}$ & $\begin{array}{l}\text { Surface runoff total } \\
\mathrm{N} \text { or organic } \mathrm{N}\end{array}$ & Leached $\mathbf{N}$ \\
\hline Tuckahoe & Fairly good & SWAT & - & - & 81 & 70 & 14 \\
\hline Greensboro & Poor & SWAT & - & - & 34 & 46 & 71 \\
\hline Beasley & Poor & AGNPS & 45 & - & - & - & - \\
\hline
\end{tabular}

Notes: $\mathrm{P}=$ phosphorus. $\mathrm{NO}_{3}=$ nitrate. $\mathrm{N}=$ nitrogen. $\mathrm{SWAT}=$ Soil and Water Assessment Tool. AGNPS = Annualized Agricultural Non-Point Source.

with knowledge of the watersheds. Major conclusions of the study are the following:

- In watersheds with mixed slopes and hydrologic soil groups, the SVI resulted in vulnerability spread out across the four categories, thus informing where efforts need to focus. The location of areas with high and low vulnerability was consistent with scientists' knowledge of vulnerability in these watersheds.

- In watersheds with uniform hydrologic soil groups, the slope was the dominant factor. In these cases, it was important to use a DEM to calculate the slope instead of using the SSURGO representative slope to obtain more discernment of vul- nerability. Two alternatives are possible: using the DEM cell-by-cell method to calculate slope and determining the SVI for each DEM cell, or using the DEM to calculate a median, average, or selected quantile of choice slope for each soil map unit. In the latter case, the SVI was then determined for each soil map unit.

- In areas where both slopes and hydrologic soil group were uniform, and in areas with uniformly elevated slopes, vulnerability was also uniform and the SVI was not able to distinguish areas that were more or less vulnerable than others. Yet, even in these cases, scientists with knowledge of the watersheds have been able to identify factors that affect vulnerability: depth of restrictive layer, clay content, slope length, and landscape position to name a few of those identified within this study.

- The SVI classification was compared with model outputs from AGNPS and SWAT in five sites. The SVI classification matched with model outputs when the predominant mode of nutrient transport matched with the SVI component. SVI runoff classification was consistent with model outputs for sites without artificial drainage (Goodwater and Tuckahoe) where sediment and nutrient movement was primarily through surface runoff. In sites with artificial drainage (Greensboro), 
model outputs for leached $\mathrm{N}$ were consistent with SVI leaching classification. Model outputs for sediment yields in Beasley and Goodwin were not fully consistent with SVI classification because primary route of sediment loss did not match with the SVI component.

Hence, the SVI can be used as a preliminary assessment tool to identify soil and topography based inherent vulnerability of a watershed and thus help in developing conservation plans and mapping vulnerability in a watershed. However, site specific information on slope length, depth to restrictive layers, landscape position, and historical information could increase the reliability and usefulness of the index. Conclusions from this study are summarized in the SVI synthesis paper by Thompson et al. (2020), along with other companion studies.

\section{References}

Alonso, C.V., and R.L. Bingner. 2000. Goodwin Creek Experimental Watershed: A unique field laboratory. Journal of Hydraulic Engineering 126(3):174-177.

Arnold, J.G., R. Srinivasan, R.S. Muttiah, and J.R. Williams. 1998. Large-area hydrologic modeling and assessment: Part I. Model development. Journal of American Water Resources Association 34(1):73-89.

Aryal, N., and M.L.Reba. 2017.Transport and transformation of nutrients and sediment in two agricultural watersheds in northeast Arkansas. Agriculture, Ecosystems and Environment 236(2017):30-42.

Baffaut, C., S. Lohani, A.L. Thompson, A.R. Davis, N. Aryal, D.L. Bjorneberg, R.L. Bingner, S.M. Dabney, L.F. Duriancik, D.E. James, K.W. King, S. Lee, G.W. McCarty, L.A. Pease, M.L. Reba, A.M. Sadeghi, M.D.Tomer, M.R. Williams, and L.M.W. Yasarer. 2020. Evaluation of the Soil Vulnerability Index for artificially drained cropland across eight Conservation Effects Assessment Project watersheds. Journal of Soil and Water Conservation 75(1):28-41, doi:10.2489/jswc.75.1.28.

Beeson, P.C., A.M. Sadeghi, M.W. Lang, M.D. Tomer, and C.S.T. Daughtry. 2014. Sediment delivery estimates in water quality models altered by resolution and source of topographic data. Journal of Environmental Quality 43:23-36.

Bjorneberg, D.L., D.T. Westermann, N.O. Nelson, and J.H. Kendrick. 2008. Conservation practice effectiveness in the irrigated Upper Snake River/Rock Creek watershed. Journal of Soil and Water Conservation 63(6):487-495, doi:10.2489/jswc.63.6.487.

Bosch, D.D., J.M. Sheridan, R.R. Lowrance, R.K. Hubbard, T.C. Strickland, G.W. Feyereisen, and D.G. Sullivan. 2007. Little River Experimental Watershed database. Water Resources Research 43(W09470), doi: 10.1029/2006WR005844.
Bryant, R.B., T.L. Veith, G.W. Feyereisen, A.R. Buda, C.D. Church, G.J. Folmar, J.P. Schmidt, C.J. Dell, and P.J.A. Kleinman. 2011. US Department of Agriculture Agricultural Research Service Mahantango Creek Watershed, Pennsylvania, United States: Physiography and history. Water Resources Research 47:W08701, doi:10.1029/2010WR010056.

Buda, A.R., P.J.A. Kleinman, M.S. Srinivasan, R.B. Bryant, and G.W. Feyereisen. 2009a. Effects of hydrology and field management on phosphorus transport in surface runoff. Journal of Environmental Quality 38(6):2273-2284.

Buda, A.R., P.J.A. Kleinman, M.S. Srinivasan, R.B. Bryant, and G.W. Feyereisen. 2009b. Factors influencing surface runoff generation from two agricultural hillslopes in central Pennsylvania. Hydrological Processes 23:1295-1312.

Busteed, P.R., D.E. Storm, M.J. White, and S.H. Stoodley. 2009. Using SWAT to target critical source sediment and phosphorus areas in the Wister Lake basin, USA. American Journal of Environmental Sciences 5(2):156-163.

Chan, R., C. Baffaut, A.L. Thompson, and E.J. Sadler. 2017. Validating the Soil Vulnerability Index for a claypan watershed. Catena 148(Part2):185-194.

Chaplot, V.A.M., and Y. Le Bissonnais. 2003. Runoff features for Interrill erosion at different rainfall intensities, slope lengths, and gradients in an agricultural loessial hillslope. Soil Science Society of American Journal 67(3):844851, doi:10.2136/sssaj2003.8440.

Chaubey, I., L. Chiang, M.W. Gitau, and S. Mohamed. 2010. Effectiveness of best management practices in improving water quality in a pasture-dominated watershed. Journal of Soil and Water Conservation 65(6):424-437, doi:10.2489/jswc.65.6.424.

Douglas-Mankin, K.R., P. Daggupati, A.Y. Sheshukov, and P.L. Barnes. 2013. Paying for sediment: Field-scale conservation practice targeting, funding, and assessment using the Soil and Water Assessment Tool. Journal of Soil and Water Conservation 68(1):41-51, doi:10.2489/ jswc.68.1.41.

Fiener, P., K. Auerswald, and K. Van Oost. 2011. Spatiotemporal patterns in land use and management affecting surface runoff response of agricultural catchments-A review. Earth Science Reviews 106(1-2):92-104.

Fisher, T.R., J.A. Benitez, K. Lee, and A.J. Sutton. 2006. History of land cover change and biogeochemical impacts in the Choptank River basin in the midAtlantic region of the US. International Journal of Remote Sensing 27(17):3683-3703.

Gale, J.A., D.E. Line, D.L. Osmond, S.W. Coffey, J. Spooner, J.A. Arnold, T.J. Hoban, and R.C. Wimberley. 1993. Evaluation of the experimental rural clean water program. National Water Quality Evaluation Project, North Carolina State University Water Quality Group, Biological and Agricultural Engineering Department,
North Carolina State University. EPA-841-R-93-005 Raleigh, NC: US Environment Protection Agency.

Gassman, P.W., M. Reyes, C.H. Green, and J.G. Arnold. 2007. The Soil and Water Assessment Tool: Historical development, applications, and future directions. Transactions of the ASABE 50(4):1211-1250.

Gburek, W.J., B.A. Needelman, and M.S. Srinivasan. 2006. Fragipan controls on runoff generation: Hydropedological implications at landscape and watershed scales. Geoderma 131(3-4):330-344.

Gesch, D., M. Oimoen, S. Greenlee, C. Nelson, M. Steuck, and D. Tyler. 2002. The national elevation dataset. Photogrammetric Engineering and Remote Sensing 68(1):5-11.

Grissinger, E.H., and J.B. Murphey. 1989. Ephemeral gully erosion in the loess uplands, Goodwin Creek watershed Northern Mississippi, USA. In Proceedings of the Fourth International Symposium on River Sedimentation, Beijing, China, 51-58. Beijing: International Symposium on River Sedimentation.

Hammer, R.D., J.H. Astroth, G.S. Henderson, and FJ.Young. 1991. Geographic information systems for soil survey and land-use planning. In Spatial Variabilities of Soils and Landforms, eds. M.J. Mausbach and L.P. Wilding, SSSA Special Publication 28, 243-270. Madison, WI: Soil Science Society of America.

Harmel, R.D., C.W. Richardson, and K.W. King. 2000. Hydrologic response of a small watershed model to generated precipitation. Transactions of the ASABE 43(6):1483-1488.

Hatfield, J.L., D.B. Jaynes, M.R. Burkart, C.A. Cambardella, T.B. Moorman, J.H. Prueger, and M.A. Smith. 1999. Water quality within the Walnut Creek watershed: Setting and farming practices. Journal of Environmental Quality 28:11-24.

Inamdar, S.P., S. Mostaghimi, M.N. Cook, K.M. Brannan, and P.W. McClellen. 2002. A long-term, watershedscale, evaluation of the impacts of animal waste BMPs on indicator bacteria concentrations. Journal of the American Water Resources Association 38(3):819-833.

Jackson-Smith, D., E. de la Hoz, M. Halling, J. McEvoy, and J. Horsburgh. 2010. Measuring conservation program BMP implementation and maintenance at the watershed scale. Journal of Soil and Water Conservation 65(6):413423, doi:10.2489/jswc.65.6.413.

Jamison, V.C, and D.B. Peters. 1967. Slope length of claypan soil affects runoff. Water Resources Research $3(2): 471-480$.

Jencso, K.G., and B.L. McGlynn. 2011. Hierarchical controls on runoff generation: Topographically driven hydrologic connectivity, geology, and vegetation. Water Resources Research 47(11):W11527, doi:10.1029/2011WR010666.

Jenks, G.F. 1967. The data model concept in statistical mapping. International Yearbook of Cartography 7:186-190. 
Jokela, W.E., J.C. Clausen, D.W. Meals, and A.N. Sharpley. 2004. Effectiveness of Agricultural Best Management Practices in Reducing Phosphorus Loading to Lake Champlain. In Lake Champlain: Partnerships and Research in the New Millennium, eds. T.O. Manley, P.L. Manley, and T.B. Mihuc, 39-52. Boston, MA: Springer.

King, K.W., P.C. Smiley Jr., B.J. Baker, and N.R. Fausey. 2008. Validation of paired watersheds for assessing conservation practices in the Upper Big Walnut Creek watershed, Ohio. Journal of Soil Water Conservation 63(6):380-395, doi:10.2489/jswc.63.6.380.

Kuhnle, R.A., R L. Binger, G.R. Foster, and E.H. Grissinger. 1996. Effect of land use changes on sediment transport in Goodwin Creek. Water Resources Research 32:3189-3196.

Lal, H. 2011. Introduction to Water Quality Index. Water Efficiency 6(5):44-49.

Lal, H., and S. McKinney. 2012. WQIag: Water quality index for runoff water from agricultural fields. Washington, DC: USDA Natural Resources Conservation Service.

Lee, S., A.M. Sadeghi, G.W. McCarty, C. Baffaut, S. Lohani, L.F. Duriancik, A.Thompson, I.Yeo, and C. Wallace. 2018. Assessing the suitability of the Soil Vulnerability Index (SVI) on identifying cropland vulnerable to nitrogen loadings using the SWAT model. Catena 167:1-12.

Lemunyon, J.L., and R.G. Gilbert. 1993. The concept and need for a phosphorus assessment tool. Journal of Production Agriculture 6(4):483-496.

Lerch, R.N., E.J. Sadler, N.R. Kitchen, K.A. Sudduth, R.J. Kremer, D.B. Myers, C. Baffaut, S.H. Anderson, and C.-H. Lin. 2008. Overview of the Mark Twain Lake/Salt River Basin Conservation Effects Assessment Project. Journal of Soil Water Conservation 63(6):345-359, doi:10.2489/jswc.63.6.345.

Lizotte, R.E., L.M.W.Yasarer, M.A. Locke, R.L. Bingner, and S.S. Knight. 2017. Lake nutrient responses to integrated conservation practices in an agricultural watershed. Journal of Environmental Quality 46(2):330-338, doi:10.2134/jeq2016.08.0324.

McCarty, G.W., L.L. McConnell, C.J. Hapeman, A. Sadeghi, C. Graff, W.D. Hively, M.W. Lang, T.R. Fisher, T. Jordan, C.P. Rice, E.E. Codling, D. Whitall, A. Lynn, J. Keppler, and M.L. Fogel. 2008. Water quality and conservation practice effects in the Choptank River watershed. Journal of Soil and Water Conservation 63(6):461-474, doi:10.2489/jswc.63.6.461.

Meals, D.W., A.N. Sharpley, and D.L. Osmond. 2012. Lessons Learned from the NIFA-CEAP: Identifying Critical Source Areas. Raleigh, NC: North Carolina State University. http://content.ces.ncsu.edu/identifyingcritical-source-areas.pdf.

Mudgal, A., C. Baffaut, S.H. Anderson, E.J. Sadler, N.R. Kitchen, K.A. Sudduth, and R.N. Lerch. 2012. Using the agricultural policy/environmental eXtender to develop and validate physically based indices for the delineation of critical management areas. Journal of Soil and Water Conservation 67(4):284-299, doi:10.2489/ jswc.67.4.284.

Nangia, V., M. Ahmad, D. Jiantao, Y. Changrong, G. Hoogenboom, M. Xurong, H. Wenqing, L. Shuang, and L. Qin. 2010. Modeling the field-scale effects of conservation agriculture on land and water productivity of rainfed maize in the Yellow River Basin, China International Journal of Agricultural and Biological Engineering 3(2):5-17

Needelman, B.A., W.J. Gburek, G.W. Petersen, A.N. Sharpley, and P.J.A. Kleinman. 2004. Surface runoff along two agricultural hillslopes with contrasting soils. Soil Science Society of America Journal 68:914-923.

Needelman, B.A., W.J. Gburek, A.N. Sharpley, and G.W. Petersen. 2001. Environmental management of soil phosphorus: Modeling spatial variability in small fields. Journal of Soil Science Society of America 65(5):1516-1522.

Nowak, P., S. Bowen, and P. Cabot. 2006. Disproportionality as a framework for linking social and biophysical systems. Society and Natural Resources 19(2):153-173.

Nowak, P.J., and P.E. Cabot. 2004. The human dimension of resource management programs. Journal of Soil and Water Conservation 59(6):128A-135A.

Osmond, D.L., D.W. Meals, D.L.H. Hoag, and M. Arabi. 2012. How to Build Better Agricultural Conservation Programs to Protect Water Quality: The National Institute of Food and Agriculture-Conservation Effects Assessment Project Experience. Ankeny, IA: Soil and Water Conservation Society.

Park, S.W., S. Mostaghimi, R.A. Cooke, and P.W. McClellan. 1994. BMP Impacts on watershed runoff, sediment, and nutrient yields. Journal of the American Water Resources Association 30(6):1011-1023.

Reba, M.L., M. Daniels, Y. Chen, A. Sharpley, J. Bouldin, T.G. Teague, P. Daniel, and C.G. Henry. 2013. A statewide network for monitoring agricultural water quality and water quantity in Arkansas. Journal of Soil and Water Conservation 68(2):45A-49A, doi:10.2489/ jswc.68.2.45A.

Renard, K.G., G.R. Foster, G.A. Weesies, and J.P. Porter. 1991. RUSLE: Revised Universal Soil Loss Equation. Journal of Soil and Water Conservation 46(1):30-33.

Ryan, R.L., D.L. Erickson, and R.D. Young. 2003. Farmers' motivations for adopting conservation practices along riparian zones in a mid-western agricultural watershed. Journal of Environmental Planning and Management 46(1):19-37, doi:10.1080/713676702.

Sharpley, A.N., T. Daniel, G. Gibson, L. Bundy, M. Cabrera, T. Sims, R. Stevens, J. Lemunyon, P. Kleinman, and R. Parry. 2006. Best management practices to minimize agricultural phosphorus impacts on water quality. USDA Agricultural Research Service Publication 163. Washington, DC: US Government Printing Office.

Sharpley, A., H.P. Jarvie, A. Buda, L. May, B. Spears, and P. Kleinman. 2013. Phosphorus legacy: Overcoming the effects of past management practices to mitigate future water quality impairment. Journal of Environmental Quality 42:1308-1326, doi:10.2134/jeq2013.03.0098.

Sharpley, A.N., P.J. Kleinman, D.N. Flaten, and A.R. Buda. 2011. Critical source area management of agricultural phosphorus: Experiences, challenges and opportunities. Water Science and Technology 64(4):945-52.

Soil Survey Staff. 2015. Web Soil Survey. Available online. Washington, DC: USDA Natural Resources Conservation Service. https://websoilsurvey.nrcs.usda.gov/.

Soil Survey Staff. 2016. Gridded Soil Survey Geographic (gSSURGO) Database for the Conterminous United States. Available online. Washington, DC: USDA Natural Resources Conservation Service. https://gdg.sc.egov. usda.gov/.

Sullivan, D.G., T.C. Strickland, and M.H. Masters. 2008 Satellite mapping of conservation tillage adoption in the Little River Experimental Watershed, Georgia. Journal of Soil and Water Conservation 63(3):112-119, doi:10.2489/jswc.63.3.112.

Strauss, P., A. Leone, M.N. Ripa, N. Turpin, J.M. Lescot, and R. Laplana. 2007. Using critical source areas for targeting cost-effective best management practices to mitigate phosphorus and sediment transfer at the watershed scale. Soil Use and Management 23(Suppl. 1):144-153.

Thompson, A.L., C. Baffaut, S. Lohani, L.F. Duriancik, M.L. Norfleet, and K. Ingram. 2020. Purpose, development, and synthesis of the Soil Vulnerability Index for inherent vulnerability classification of cropland soils. Journal of Soil and Water Conservation 75(1):1-11, doi:10.2489/ jswc.75.1.1.

Tomer, M.D., and D.E. James. 2004. Do soil surveys and terrain analyses identify similar priority sites for conservation? Soil Science Society of America Journal 68(6):1905-1915.

Tomer, M.D., D.E.James, and T.M. Isenhart. 2003. Optimizing the placement of riparian practices in a watershed using terrain analysis. Journal of Soil and Water Conservation 58(4):198-206.

Tomer, M.D., and M.A. Locke. 2011. The challenge of documenting water quality benefits of conservation practices:A review of USDA-ARS's conservation effects assessment project watershed studies. Water Science and Technology 64(1):300-310.

Tomer, M.D., S.A. Porter, D.E. James, K.M.B. Boomer, J.A Kostel, and E. McLellan. 2013. Combining precision conservation technologies into a flexible framework to facilitate agricultural watershed planning. Journal of Soil and Water Conservation 68(5):113A-120A, doi:10.2489/jswc.68.5.113A.

Tomer, M.D., E.J. Sadler, R.E. Lizotte, R.B. Bryant, T.L. Potter, M.T. Moore, T.L. Veith, C. Baffaut, M.A. Locke, and M.R. Walbridge. 2014. A decade of conservation effects assessment research by the USDA Agricultural Research Service: Progress overview and future outlook. Journal of Soil and Water Conservation 69(5):365-373, doi:10.2489/jswc.69.5.365. 
USDA NRCS (Natural Resources Conservation Service). 2007. Chapter 7 Hydrologic Soil Groups, Part 630 Hydrology. In National Engineering Handbook. Washington, DC: USDA Natural Resources Conservation Service.

USDA NRCS. 2012. Assessment of the Effects of Conservation Practices on Cultivated Cropland in the Upper Mississippi River Basin, 189. Washington, DC: USDA Natural Resources Conservation Service.

USDA NRCS. 2016. Effects of Conservation Practice Adoption on Cultivated Cropland Acres in Western Lake Erie Basin, 2003-06 and 2012. Conservation Effects Assessment Project - Cropland, Special Study Report. Washington, DC: USDA Natural Resources Conservation Service.

Veith, T.L., J.E. Richards, S.C. Goslee, A.S. Collick, R.B. Bryant, D.A. Miller, B.W. Bills, A.R. Buda, R.L. Sebring, and P.J.A. Kleinman. 2015. Navigating spatial and temporal complexity in developing a long-term land use database for an agricultural watershed. Journal of Soil and Water Conservation 70(5):288-296, doi:10.2489/ jswc.70.5.288.

Williams, J.R., and R.C. Izaurralde. 2005. The APEX model. BREC Report No. 2005-02. Temple, TX: Texas A\&M University.

Williams, M.R., K.W. King, and N.R. Fausey. 2015. Drainage water management effects on tile discharge and water quality. Agricultural Water Management 148:43-51.

Wilson, G.V., J.R. Rigby, and S.M. Dabney. 2015. Soil pipe collapses in a loess pasture of Goodwin Creek watershed, Mississippi: Role of soil properties and past land use. Earth Surface Processes and Landforms 40:1148-1463.

Yang, W., M. Khanna, and F. Richard. 2005. Effectiveness of conservation programs in Illinois and gains from targeting. American Journal of Agricultural Economics 87(5):1248-1255.

Yasarer, L.M.W., S. Lohani, R.L. Bingner, M.A. Locke, C. Baffaut, and A.L. Thompson. 2020. Assessment of the Soil Vulnerability Index and comparison with AnnGNPS in two Lower Mississippi River Basin watersheds. Journal of Soil and Water Conservation 75(1):53-61, doi:10.2489/jswc.75.1.53. 